\title{
Avian influenza in Poland
}

\author{
Krzysztof Śmietanka ${ }^{\bowtie}$ and Zenon Minta \\ Department of Poultry Diseases, National Veterinary Research Institute, Puławy, Poland
}

\begin{abstract}
Poland has experienced four episodes of avian influenza (AI) outbreaks over the past two decades. The first epidemic was caused by a low pathogenicity (LPAIV) H7N7 subtype and occurred in fattening and breeder turkeys in 1995. Two waves of H5N1 high pathogenicity avian influenza (HPAl) took place in 2006 and 2007. In spring 2006, 64 cases of the H5N1 virus were detected, mostly in mute swans. In December 2007, ten outbreaks of H5N1 HPAl were detected in commercial poultry $(n=9)$ and wild birds kept in captivity $(n=1)$. The outbreaks in 2006 and 2007 were caused by genetically similar but clearly distinguishable viruses of the 2.2 clade. In 2013, an H9N2 avian influenza virus was detected in 4 fattening turkey holdings. The virus was low pathogenic and a phylogenetic study has shown a close relatedness to the Eurasian lineage of AIV of the wild bird origin. Neither preventive nor prophylactic vaccinations have ever been used in poultry or other birds. Emergency vaccinations using autogenous vaccine were introduced only to control the H7N7 LPAI outbreaks in 1995. The baseline surveillance for AI in live migratory birds and poultry provides a valuable insight into the ecology of AIV at the wild and domestic bird interface. Passive surveillance is in place of early detection of HPAIV infection in dead or moribund birds.
\end{abstract}

Key words: avian influenza, $\mathrm{H} 5 \mathrm{~N} 1$ virus

Received: 27 May, 2014; revised: 18 August, 2014; accepted: 20 August, 2014; available on-line: 01 September, 2014

\section{INTRODUCTION}

Avian influenza (AI) is an infectious and contagious disease of birds. The aetiological agent is a negativesense, RNA virus with a segmented genome that belongs to the Orthomyxoviridae family (Cox et al., 2000). Based on the surface glycoproteins, haemagglutinin (HA) and neuraminidase (NA), avian influenza viruses (AIV) have been divided into $16 \mathrm{HA}$ subtypes and 9 NA subtypes that replicate in birds in different combinations (e.g. H1N1, H5N1, H7N7, etc.) (Alexander, 2007a). Recently, H17N10 and H18N11 subtypes have been recognized in bats, but there is no evidence so far that they circulate in birds or other species of animals (Tong et al., 2012; Tong et al., 2013). Viruses commonly found in the wild bird reservoir are in most cases avirulent or cause only mild clinical signs, e.g. reduced body weight (Kuiken, 2013), and are referred to as low pathogenicity avian influenza viruses (LPAIV). Wild birds shed the LPAIV mostly through faeces, and infection via faecaloral route remains the major mode of transmission to susceptible individuals (Webster et al., 1992). The circula- tion of LPAIV in wild birds is accompanied by frequent episodes of incursions into domestic populations since phylogenetic studies have shown that AIV detected in wild birds and poultry are often closely related and share common ancestors (Campitelli et al., 2004; Munster et al., 2005). Some of these infections are restricted to single or a few outbreaks and then fade away, while other (e.g. avian influenza H9N2 in the Middle East and Far-East Asia) spread efficiently and become endemic in susceptible populations (Alexander, 2007b; Brown, 2010). LPAIV infections in poultry can be either subclinical or associated with respiratory or digestive tract disorders and in breeder flocks - with a drop in egg production. Mortality in chickens is usually low, whereas in turkeys can be high (Capua et al., 2000). Of the 16 HA subtypes of AIV detected in wild birds, only a fraction of $\mathrm{H} 5$ and H7 subtypes have the potential to mutate and cause high pathogenicity avian influenza (HPAI) - a systemic disorder with a violent clinical course and high mortality rate (Alexander, 2007a). It was shown that conversion from LPAI to HPAI is correlated with the acquisition of multiple basic amino acids (arginine and lysine) at the region between the two HA1 and HA2, called the cleavage site of HA (Garten \& Klenk, 2008). All infections in poultry caused by AIV of any subtype fulfilling the in vivo criteria for high virulence laid down in the Terrestrial Animal Health Code of the World Organisation for Animal Health (OIE), and also all $\mathrm{H} 5$ and $\mathrm{H} 7 \mathrm{AIV}$, irrespective of virulence, are reported to animal health authorities as notifiable avian influenza (OIE, 2013). The actions taken upon detection of H5 or H7 LPAI in poultry are mostly precautionary, since measures (e.g. culling) often pertain to clinically healthy flocks, but the rationale for such procedures is to minimize the risk of mutation from LPAIV into HPAIV. It must be stressed that the division into LPAIV and HPAIV is based on their virulence for chickens and HPAIV can cause subclinical infections in certain species of birds, mostly waterfowl. Although first recognized in 1878 as "fowl plague", the outbreaks of HPAI in birds have been systematically documented since 1959 and so far more than 30 epidemics have been confirmed (Swayne et al., 2013). Avian influenza raises public attention due to the zoonotic potential of selected viruses of $\mathrm{H} 5, \mathrm{H} 7, \mathrm{H} 9$ and, more recently, H10 subtypes (Lin et al., 2000; Van Kerkhove, 2013; Abdelwhab et al., 2014; To et al., 2014). Interestingly, there is no clear correlation between the virulence of AIV strains for birds and humans, i.e. highly pathogenic H5N1 AIV causes high mortality in people and so does the low pathogenic H7N9 virus.

e-mail: ksmiet@piwet.pulawy.pl

Abbreviations: Al, Avian influenza; AIV, avian influenza viruses; HA, haemagglutinin; HI, haemagglutination-inhibition; NA, neuraminidase; LPAIV, low pathogenicity avian influenza viruses. 


\section{LOW PATHOGENIC AVIAN INFLUENZA H7N7 IN 1995}

The first cases of a laboratory-confirmed AI occurred in Poland in 1995 in meat and breeder turkeys (Minta \& Koncicki, 1996). The meat turkeys were usually 3-12 weeks old at the onset of clinical disease, while birds from breeder flocks exhibited problems during both growing and laying periods. The economic losses were mostly associated with the secondary infections and with a long-lasting drop in egg production in layers. The isolated virus was identified by the haemagglutination-inhibition ( $\mathrm{HI}$ ) test as the $\mathrm{H} 7$ subtype, whereas an in vivo test (intravenous pathogenicity index, IVPI) determined its low pathogenicity (IVPI $=0.0)$. The archived stock of the virus was recovered two decades later and RT-PCR, coupled with sequencing, enabled more accurate identification and characterization of the virus that was found to belong to the H7N7 subtype. The H7 gene is phylogenetically grouped closely to AIV viruses that were isolated from exotic birds in Europe and USA in 1989-1992. However, it clearly showed a tendency to form a separate sub-clade (data not published). The sequence database is incomplete for the lineage of viruses circulating in the mid-90s of the 20th century and is represented by the two Polish turkey-derived strains of H7N7. The source of introduction of the virus to the turkey population in Poland at that time remained unknown. Control measures applied in the region where the outbreaks were confirmed included vaccinations using an inactivated autogenous vaccine prepared from the index-case virus.

\section{NATIONAL REFERENCE LABORATORY FOR AVIAN INFLUENZA}

The perspective of Poland's accession to the European Union in 2004 was a catalyst for adjusting Polish regulations concerning diagnosis of infectious animal diseases, including avian influenza. The process required much effort and resources, such as re-construction of laboratory infrastructure, including construction of the new laboratory facilities, improvement of diagnostic methods through the development and adaptation of molecular biology techniques, and implementation of systematic surveillance for AIV infections in domestic and wild birds. The laboratory located at the National Veterinary Research Institute, Department of Poultry Diseases in Pulawy was officially nominated as the National Reference Laboratory (NRL) for Avian Influenza in 2003. The first surveillance activities co-financed from the EU budget were implemented in 2003, even though a pilot study was carried out a few years earlier (Smietanka et al., 2005). Altogether, in 2001-2004 more than 20,000 samples collected from chickens, turkeys, geese, ducks, pheasants, ostriches, pigeons and guinea-fowls were tested serologically or virologically, and the presence of antibodies was found in sera collected from single flocks of geese, chicken and turkeys. No active AIV infection was found in poultry.

In 2005, the unprecedented global spread of H5N1 from South-East Asia to Europe accelerated the advent of molecular techniques for the diagnosis of avian influenza. The first RT-PCR methods applied at NRL were based on previously published methods for detection of highly conserved regions of NP and M genes (Domanska-Blicharz et al., 2006). The methods, albeit validated on a limited number of samples, proved to be useful tools for the generic detection of influenza viruses, since not only AIV were detected in the validation process, but swine and equine influenza viruses as well. The transition from two-step conventional RT-PCR to one-step RT-PCR, and more importantly one-step real time RTPCR methods (Spackman et al., 2002), streamlined the throughput capabilities. Moreover, subtype-specific (H5, $\mathrm{H} 7$ and N1 subtypes) real time and conventional RTPCR were also implemented (Payungporn et al., 2006; Slomka et al., 2007; Slomka et al., 2009) and enabled more detailed characterization of the most crucial AIV strains.

\section{HIGHLY PATHOGENIC AVIAN INFLUENZA H5N1 IN 2006 AND 2007}

Large-scale outbreaks of H5N1 HPAI that emerged in Europe at the beginning of 2006 were most likely associated with the harsh weather conditions and a massive aggregation of wild birds in areas along the $0^{\circ} \mathrm{C}$ isotherm (Reperant et al., 2010). The high densities of wild birds favoured the spread of infection within susceptible populations. The major focus of H5N1 HPAI occurred on the island of Ruegen in Germany, where more than 100 birds were found to be infected (Globig et al., 2009). Further escalation and spread of the epidemic to Poland was only a matter of time and, indeed, the first cases of H5N1 outbreaks were confirmed on March 4, 2006 (Minta et al., 2007). The virus was detected in the city of Torun in a flock of more than 100 swans, of which four died (H5N1 virus was confirmed by RT-PCR). The viral RNA was subsequently found in 32 asymptomatic swans (all of them were euthanized), while the presence of antiH5 antibodies was detected by the HI test in about $70 \%$ of the birds. Interestingly, positive $\mathrm{HI}$ reactions were also found against other HA subtypes of AIV, mostly H1 (53\% swans) and H9 (21\% swans) (Smietanka et al., 2008).

The ornithological investigation performed in the flock of swans from Torun, including evaluation of biometrical features, sex and age profiles and alleged migration routes, had provided an additional dataset for analysis (Włodarczyk \& Szeleszczuk, 2008). The flock comprised 66 males and 44 females, and $70 \%$ of the birds were adult and in good health condition. Statistical analysis demonstrated a significantly higher body weight in females shedding the virus, but the value of this finding is difficult to assess as other features, such as previous exposure to infection measured by serology, were not taken into consideration in these calculations. The swans from Torun were part of a population migrating along the Vistula and Noteć river valleys which chose the Vistula river valley as their wintering site. Some individuals used to visit regularly this specific location. For example, the ring number of one male provided evidence that the bird previously wintered at that site at least twice. Based on the behaviour of swans, which tend to terminate their movements towards wintering grounds at the turn of November/ December of the previous year with very little or no influx of new birds thereafter, the authors concluded that infections with the $\mathrm{H} 5 \mathrm{~N} 1$ virus in that area might have been present long before the first confirmed detection, but had gone unnoticed.

In addition to the Torun outbreak, infections with H5N1 HPAI were confirmed in 2006 between March and May in Świnoujście, Bydgoszcz, Grudziądz as well as near Kostrzyń upon the Odra and Warta (Fig. 1) in 64 wild birds: 61 mute swans (Cygnus olor), 1 goosander (Mergus merganser), 1 gashawk (Accipiter gentilis) and 1 grey 


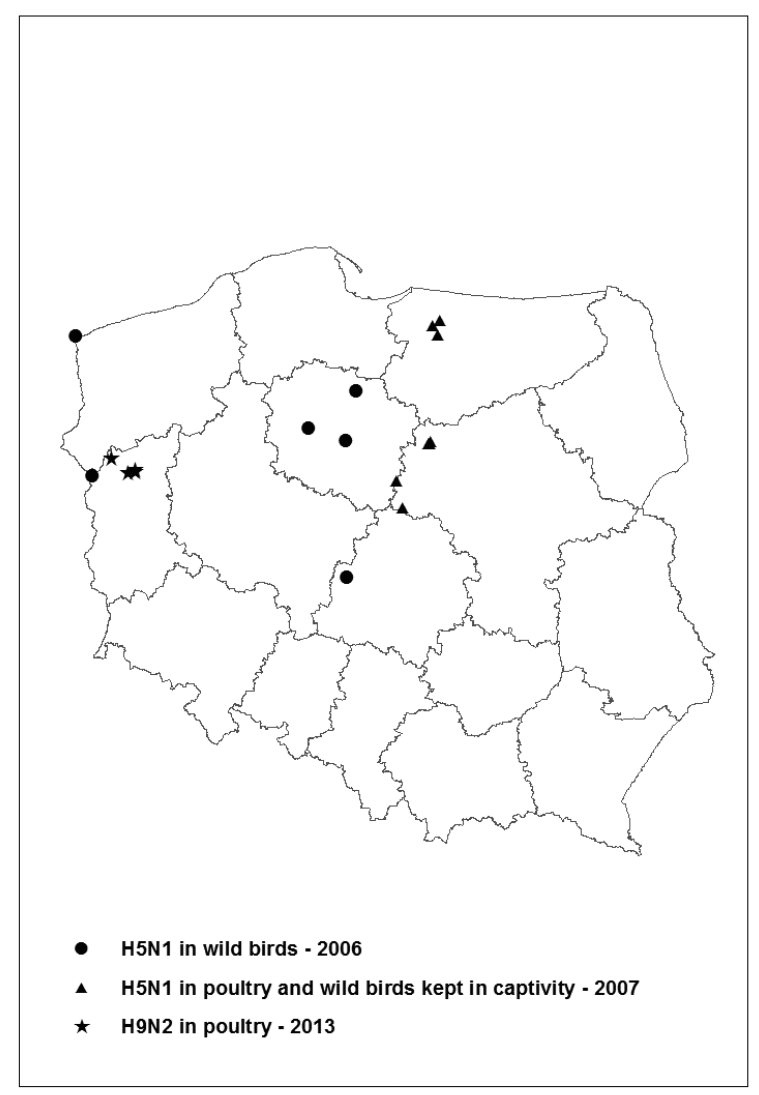

Figure 1. Avian influenza outbreaks in Poland in 2006-2013 (ArcGIS 10.1, Esri Inc.)

heron (Ardea cinerea). No outbreaks in poultry were detected in 2006 (Minta et al., 2007).

The detection of H5N1 HPAI incidents in the EU, including Poland, was accomplished exclusively through the finding of dead infected birds (Hesterberg et al., 2009). Since the reporting of mortality in wild birds was preceded by direct observations of the field situation performed not only by ornithologists and bird watchers, but mostly by non-expert city dwellers, the majority of H5N1 cases in Poland detected in towns and cities did not reflect the real distribution of the outbreaks, as cases of the disease in difficult to reach areas or locations with low wild-bird densities might have been missed. Similarly, the high proportion of mute swans detected during the epidemic in 2006 was influenced by two factors: a relatively high susceptibility of this species (associated with an elevated mortality rate), but also an aggregation of swans close to inhabited regions, which increased the chance of dead carcasses being found and reported to veterinary authorities.

After the H5N1 HPAI outbreak in May 2006, no further cases had been diagnosed until late 2007. On December 1, 2007, the NRL in Puławy confirmed the first outbreaks of H5N1 HPAI in two meat turkey holdings in central Poland (Smietanka et al., 2009). The symptoms included depression, swelling of infraorbital sinuses and haemorrhagic lesions in internal organs. Up to December 22 , the presence of the virus was detected in three flocks of commercial layer chickens, four backyard flocks with mixed species (chickens, ducks and geese) as well as in 2 buzzards (Buteo buteo) and 1 white stork (Ciconia ciconia) kept in captivity in an avian asylum in 2 provinces: Mazowieckie and Warmińsko-Mazurskie (Fig. 1). The size of the affected holdings varied from a few birds (backyard flocks) to 385,000 chicken layers. Control measures applied after detection of the outbreaks comprised the culling of birds in infected holdings, movement restrictions, disinfection and a quarantine. Altogether, more than 900000 birds had been culled, and the costs incurred by the epidemics exceeded $12 \mathrm{mln}$ PLN (Smietanka et al., 2009). Vaccinations of poultry and other captive birds were not performed during the H5N1 epidemics in Poland.

Phylogenetic analysis carried out for all eight genome segments of selected H5N1 isolates has shown that two separate introductions of genetically similar but clearly distinct clades, 2.2.2 (or 2.2 sublineage II) and 2.2.3 (or 2.2.sublineage III), gave rise to the epidemics in 2006 and 2007, respectively (Smietanka et al., 2010). Interestingly, although the outbreaks in Poland in 2007 coincided with the re-emergence of the H5N1 virus in Germany, the common origin of incursions was excluded on the basis of a more in-depth analysis of concatenated coding regions of AIV genomes (Haase et al., 2010).

Several important amino-acid residues have been identified in proteins in $\mathrm{H} 5 \mathrm{~N} 1$ viruses. The identification of molecular characteristics associated with virulence, host adaptation and drug resistance became an intrinsic part of the diagnostic process. Analysis of all tested H5N1 strains has revealed the polybasic amino acid profile PQGERRRKKR*GLF at the HA cleavage site (suggestive of high virulence for chickens), 238Q and 240G residues at the receptor binding site of HA (indicative of preferable binding to $\alpha 2-3$-linked sialic acid, thus showing typical avian-like receptor specificity), the $274 \mathrm{H}$ and $294 \mathrm{~N}$ motif at the NA (typical of influenza viruses susceptible to oseltamivir) and E627K mutation at the PB2 protein (associated with increased replication capacities in mammalian cells) (Smietanka, et al., 2010).

\section{LOW PATHOGENIC AVIAN INFLUENZA H9N2 IN 2013- 2014}

In the spring of 2013, Poland experienced outbreaks of H9N2 low pathogenicity avian influenza in fattening turkeys in the western part of the country. Sick birds presented decreased feed and water intake, respiratory signs and different (but usually low) mortality rates (Smietanka et al., 2014). The H9N2 subtype of AIV has been widely recognized in wild and domestic birds and infections with this virus have been endemic in poultry in regions from the Middle East to Far-East Asia for more than a decade (Alexander, 2007b; Brown, 2010). Although the H9N2 virus is of low pathogenicity, infections often lead to high economic losses, especially in the presence of concomitant bacterial infections (Pan et al., 2012). The major concern is associated with the zoonotic potential of the H9N2 virus resulting from the human-like SA 2,6 receptor specificity (Imai \& Kawaoka, 2012). So far very few laboratory-confirmed human cases have been reported, but serological investigations have revealed the presence of seroreagents in sera collected from poultry workers in endemic regions and therefore, the virus is thought to pose an occupational risk (Huang et al., 2013).

There was a spatial and temporal association between all detected outbreaks (Fig. 1). Even more importantly, turkeys from 2 out of 4 clinically affected flocks (including the index case farm) were hatched and reared for the first weeks of life in Germany and then moved to Poland, hence raising an assumption that H9N2 outbreaks 


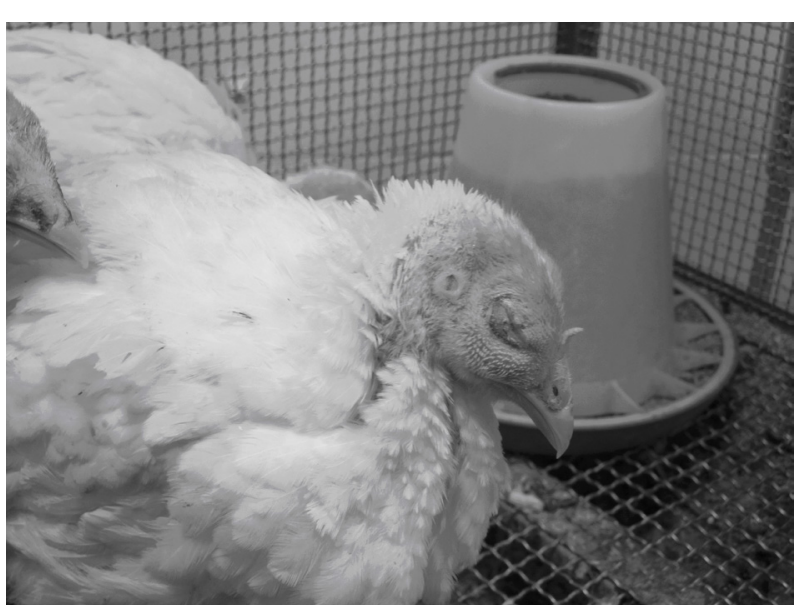

Figure 2. Turkey experimentally infected with low pathogenic avian influenza virus subtype H9N2: depression and severe edema of infraorbital sinuses

in Poland were directly linked to the epidemic that had been present in Germany since at least 2012 (Popp, 2013; Rönchen, 2013). Moreover, results of phylogenetic studies clearly suggested that wild birds acted as the primary source of H9N2 virus infection for the population of domestic birds in Europe. Interestingly, a genetically similar H9N2 virus was also detected in October 2013 in a common coot (Fulica atra) in the province of Lower Silesia. Even more importantly, the outbreaks were not related to the ongoing epidemic of H9N2 AI in the Middle East, Central and East Asia. The analysis of molecular signatures in the HA and NA glycoproteins demonstrated the avian-like $\mathrm{SA} \alpha 2,3$ receptor specificity (glutamine at position 234 of $\mathrm{HA}$ ) and features suggestive of a sustained adaptation to gallinaceous poultry (a deletion of 26 amino acids in the stalk region of NA). The index-case H9N2 isolate showed low pathogenicity for chickens after intravenous as well as mixed intraocular and intranasal inoculation, but experimental infection of commercial turkeys resulted in respiratory signs and mortality (Fig. 2). However, the presence of Ornithobacterium rbinotracheale and Bordetella avium DNA was also found by PCR in turkeys from field outbreaks and experimental infection, suggestive of a synergistic effect of H9N2 AIV and other turkey pathogens. The subsequent serological investigation performed in 92 poultry flocks demonstrated the presence of antibodies against the H9N2 subtype only in two additional meat turkey flocks located in the same province as clinically affected flocks. No further cases in poultry were confirmed until April 2014, when the presence of H9 AIV was detected in two turkey flocks in Western Poland (not published).

\section{THE RESULTS OF ACTIVE SURVEILLANCE FOR AVIAN INFLUENZA IN POULTRY AND WILD BIRDS}

The serological survey programme that was initiated in Poland in 2003 is mandatory in the European Union since 2005 (Breed et al., 2010). The serological active surveillance performed in the years 2009-2013 on more than 2400 clinically healthy poultry flocks has demonstrated the presence of antibodies to AIV in 8 breeder geese holdings ( 7 flocks were positive for $\mathrm{H} 5$ and 1 flock for the H7 subtype) and 1 breeder duck flock (positive for H5 subtype) (Pikuła et al., 2014). The lack of clinical signs together with the open system of breeding suggested transmission of LPAIV from the wild bird population. Indeed, the analysis of avian influenza outbreaks in poultry all over the world has pointed at wild birds as the primary source of the virus. The monitoring initiated in Poland in 2002 in the free-living population of birds has been continued in subsequent years, taking advantage of the collaboration with ornithologists in order to ensure proper sampling, storage and shipment of samples. Results allowed for the identification of interesting hotspots, such as Jeziorsko artificial reservoir in central Poland, an important stopover site for wild birds migrating towards wintering grounds, in which multiple AIV have been isolated over the years, including $\mathrm{H} 5$ AIV subtypes, potentially dangerous for poultry. The sampling performed at Jeziorsko in the high-risk seasons (late summer/early autumn) resulted in a relatively high detection rate $(3.8 \%)$ and enabled identification of interesting events, e.g. the simultaneous detection of three viruses - AIV subtypes $\mathrm{H} 4$ and $\mathrm{H} 5$ as well as avian paramyxovirus type $4-$ in three common teals captured at the same location and time (Smietanka et al., 2012).

Avian influenza viruses circulate also in wild birds from urban areas, which was shown previously in relation to H5N1 HPAIV during the 2006 outbreak in Poland. However, the aforementioned epidemic represented an unusual pattern in terms of AIV ecology, since wild birds are natural hosts for low pathogenicity, but not highly pathogenic viruses. The surveillance for LPAIV carried out in Dutch cities in between 2006-2009 has shown the presence of the virus in $0.5 \%$ of birds (Verhagen et al., 2012). In Poland, wild bird sampling for the purpose of LPAIV monitoring in urbanized areas has been focused on the Gdańsk, Gdynia, Sopot area. The surveillance study in Gdańsk provided some interesting data on the co-circulating AIV of H7N7 subtype in mallards (Anas platyrbynchos) (Smietanka et al., 2011). The phylogenetic investigation revealed a close relationship between N7 genes from two viruses detected over a period of 1 year in mallards sampled at the same pond, which suggests that AIV can persist in a resident population of mallards for a long period of time. On the other hand, the very close similarity between HA genes $(99.8 \%)$ of the virus from city mallards in Gdańsk and an $\mathrm{H} 7$ AIV detected in a holding of domestic geese in the Czech Republic possibly provide evidence of a spread of viruses between resident and migratory populations combined with long-distance dispersal and transmission to domestic poultry.

Although Poland has never experienced epidemics in poultry of the magnitudes observed in South East Asia or other countries in Europe, e.g. in Italy in 1999/2000 or in the Netherlands in 2003 (Capua et al., 2000; Stegeman et al., 2004), the situation described in this paper exemplifies the complex nature of avian influenza epidemiology and the importance of wild and domestic bird interface in the ecology of AIV infections.

\section{REFERENCES}

Abdelwhab EM, Veits J, Mettenleiter TC (2014) Prevalence and control of $\mathrm{H} 7$ avian influenza viruses in birds and humans. Epidemiol Infect 142: 896-920.

Alexander DJ (2007a) An overview of the epidemiology of avian influenza. Vaccine, 25: 5637-5644.

Alexander DJ (2007b) Summary of avian influenza activity in Europe, Asia, Africa, and Australasia, 2002-2006. Avian Dis 51: 161-166.

Breed AC, Harris K, Hesterberg U, Gould G, Londt BZ, Brown IH, Cook AJC (2010) Surveillance for avian influenza in wild birds in the European Union in 2007. Avian Dis 54: 399-404.

Brown IH (2010) Summary of avian influenza activity in Europe, Asia, and Africa, 2006-2009. Avian Dis 54: 187-193. 
Campitelli L, Mogavero E, De Marco MA, Delogu M, Puzelli S, Frezza F, Facchini M, Chiapponi C, Foni E, Cordioli P, Webby R, Barigazzi G, Webster RG, Donatelli I (2004) Interspecies transmission of an $\mathrm{H} 7 \mathrm{~N} 3$ influenza virus from wild birds to intensively reared domestic poultry in Italy. Virology 323: 24-36.

Capua I, Mutinelli F, Marangon S, Alexander DJ (2000) H7N1 avian influenza in Italy (1999 to 2000) in intensively reared chickens and turkeys. Avian Pathol 29: 537-543.

Cox NJ, Fuller F, Kaverin N, Klenk HD, Lamb RA, Mahy BW, McCauley J, Nakamura K, Palese P, Webster R (2000) Orthomyxoviridae. In Virus Taxonomy, Seventh Report of the International Committee on Taxonomy of Viruses. Van Regenmortel MH, Fauquet CM, Bishop DHL, Carstens EB, Estes MK, Lemon SM, Maniloff J, Mayo MA, McGeoch DJ, Pringle CR, Wickner RB, eds. pp 585-597. Academic Press, San Diego.

Domanska-Blicharz K, Smietanka K, Minta Z (2006) Molecular methods for the detection of avian influenza type A viruses. Bull Vet Inst Pulawy 50: 287-291.

Garten W, Klenk HD (2008) Cleavage activation of the influenza virus hemagglutinin and its role in pathogenesis. In Avian influenza, Klenk HD, Matrosovich MN, Stech J, eds, Monogr Virol vol 27, pp 156-167. Basel, Karger.

Globig A, Staubach C, Beer M, Koppen U, Fiedler W, Nieburg M, Wilking H, Starick E, Teifke JP, Werner O, Unger F, Grund C, Wolf C, Roost H, Feldhusen F, Conraths FJ, Mettenleiter TC, Harder TC (2009) Epidemiological and ornithological aspects of outbreaks of highly pathogenic avian influenza virus H5N1 of Asian lineage in wild birds in Germany, 2006 and 2007. Transbound Emerg Dis 56: $57-72$

Haase M, Starick E, Fereidouni S, Strebelow G, Grund C, Seeland A, Scheuner C, Cieslik D, Smietanka K, Minta Z, Zorman-Rojs O, Mojzis M, Goletic T, Jestin V, Schulenburg B, Pybus O, Mettenleiter T, Beer M, Harder T (2010) Possible sources and spreading routes of highly pathogenic avian influenza virus subtype H5N1 infections in poultry and wild birds in Central Europe in 2007 inferred through likelihood analyses. Infect Genet Evol 10: 1075-1084.

Hesterberg U, Harris K, Stroud D, Guberti V, Busani L, Pittman M, Piazza V, Cook A, Brown I (2009) Avian influenza surveillance in wild birds in the European Union in 2006. Influenza Other Respir Viruses 3: 1-14.

Huang R, Wang AR, Liu ZH, Liang W, Li XX, Tang YJ, Miao ZM, Chai TJ (2013) Seroprevalence of avian influenza H9N2 among poultry workers in Shandong Province, China. Eur J Clin Microbiol Infect Dis 32: 1347-1351.

Imai M, Kawaoka Y (2012) The role of receptor binding specificity in interspecies transmission of influenza viruses. Curr Opin Virol 2 . $160-167$.

Kuiken T (2013) Is low pathogenic avian influenza virus virulent for wild waterbirds? Proc Biol Sci 280: 20130990.

Lin YP, Shaw M, Gregory V, Cameron K, Lim W, Klimov A, Subbarao K, Guan Y, Krauss S, Shortridge K, Webster R, Cox N, Hay A (2000) Avian-to-human transmission of H9N2 subtype influenza A viruses: relationship between $\mathrm{H} 9 \mathrm{~N} 2$ and $\mathrm{H} 5 \mathrm{~N} 1$ human isolates. Proc Natl Acad Sci U S A 97: 9654-9658.

Minta Z, Koncicki A (1996) New diseases of turkeys. In: Scientific Symposia, 3rd International Fair of Tecbnology and Veterinary Organization PRO ANIMALI'96. Wrocław 29.04-1.05.1996, pp I-5-I-7.

Minta Z, Smietanka K, Domanska-Blicharz K, Tomczyk G, Wijaszka T (2007) Highly pathogenic avian influenza H5N1 in wild birds in Poland - analysis of first cases. Med Weter 63: 1349-1352 (in Polish).

Munster VJ, Wallensten A, Baas C, Rimmelzwaan GF, Schutten M, Olsen B, Osterhaus AD, Fouchier RA (2005) Mallards and highly pathogenic avian influenza ancestral viruses, northern Europe. Emerg Infect Dis 11: 1545-1551.

OIE (2013) Terrestrial Animal Health Code, chapter 10.4 Infections with avian influenza viruses, available at http://www.oie.int/index. php?id $=169 \& \mathrm{~L}=0 \&$ htmfile $=$ chapitre_1.10.4.htm (accessed 5th May 2014)

Pan Q, Liu A, Zhang F, Ling Y, Ou C, Hou N, He C (2012) Co-infection of broilers with Ornithobacterium rbinotracheale and H9N2 avian influenza virus. BMC Vet Res 8: 104.

Payungporn S, Chutinimitkul S, Chaisingh A, Damrongwantanapokin S, Buranathai C, Amonsin A, Theamboonlers A, Poovorawan Y (2006) Single step multiplex real-time RT-PCR for H5N1 influenza A virus detection. J Virol Methods, 131: 143-147.

Pikuła A, Smietanka K, Lisowska A, Minta Z (2014) Active surveillance in poultry in Poland for avian influenza subtypes $\mathrm{H} 5$ and $\mathrm{H} 7$. Acta Biocbim Pol 61: 459-463.

Popp C, Lueschow D, Hafez HM (2013) Report on recent avian influenza virus (AIV) H9N2 outbreaks in commercial turkey flocks in Southern Germany. Proceedings of the XVIIIth International Congress of the World Veterinary Poultry Association (p. 491). Nantes, France.

Reperant LA, Fuckar NS, Osterhaus AD, Dobson AP, Kuiken T (2010) Spatial and temporal association of outbreaks of H5N1 influenza virus infection in wild birds with the 0 degrees $C$ isotherm. PLoS Pathog 6: e1000854.
Rönchen S (2013) Avian influenza H9N2 in Germany: dynamics of spreading and molecular changes in a dense poultry populated area. In Abstracts of 7th "Hafez" International Symposium on Turkey Production. May 30th-June 1st 2013, Hafez HM, ed. Berlin, Germany.

Slomka MJ, Pavlidis T, Banks J, Shell W, McNally A, Essen S, Brown IH (2007) Validated H5 Eurasian real-time reverse transcriptase-polymerase chain reaction and its application in H5N1 outbreaks in 2005-2006. Avian Dis 51: 373-377.

Slomka MJ, Pavlidis T, Coward VJ, Voermans J, Koch G, Hanna A, Banks J, Brown IH (2009) Validated RealTime reverse transcriptase PCR methods for the diagnosis and pathotyping of Eurasian H7 avian influenza viruses. Influenza Other Respir Viruses 3: 151-164.

Smietanka K, Minta Z, Tomczyk G, Domanska-Blicharz K, Bartnicka B, Szewczyk B, Grzywaczewski G (2005) Prevalence of avian influenza virus infections in poultry and wild birds. Med Weter 61: 676-679.

Smietanka K, Minta Z, Domanska-Blicharz K, Tomczyk G, Wijaszka T (2008) Avian Influenza H5N1 Outbreak in a Flock of Mute Swans in the City of Torun, Poland, in 2006. Bull Vet Inst Pulawy 52: 491-495

Smietanka K, Minta Z, Domanska-Blicharz K, Tomczyk G, Wijaszka T, Zwiazek J, Batorczak Z, Bartoszewicz L (2009) ) Highly pathogenic avian influenza H5N1 cases in Poland in 2007. Med Weter 65: 115-118 (in Polish).

Smietanka K, Fusaro A, Domanska-Blicharz K, Salviato A, Monne I, Dundon WG, Cattoli G, Minta Z (2010) Full-length genome sequencing of the Polish HPAI H5N1 viruses suggests separate introductions in 2006 and 2007. Avian Dis 54: 335-339.

Smietanka K, Pikula A, Minta Z, Meissner W (2011) Evidence of persistence and multiple genetic modifications of H7N7 low-pathogenic avian influenza virus in wild mallards in Poland provided by phylogenetic studies. Avian Pathol 40: 131-138.

Smietanka K, Minta Z, Wlodarczyk R, Wyrostek K, Jozwiak M, Olszewska M, Minias P, Kaczmarek K, Janiszewski T, Kleszcz A (2012) Avian influenza viruses in wild birds at the Jeziorsko reservoir in Poland in 2008-2010. Pol J Vet Sci 15: 323-328.

Smietanka K, Minta Z, Świętoń E, Olszewska M, Jóźwiak M, Domańska-Blicharz K, Wyrostek K, Tomczyk G, Pikuła A (2014) Avian influenza H9N2 subtype in Poland - characterization of the isolates and evidence of concomitant infection. Avian Pathol (in press, DOI 10.1080/03079457.2014.952221).

Spackman E, Senne DA, Myers TJ, Bulaga LL, Garber LP, Perdue ML, Lohman K, Daum LT, Suarez DL (2002) Development of a real-time reverse transcriptase PCR assay for type A influenza virus and the avian $\mathrm{H} 5$ and $\mathrm{H} 7$ hemagglutinin subtypes. J Clin Microbiol 40: $3256-3260$.

Stegeman A, Bouma A, Elbers AR, de Jong MC, Nodelijk G, de Klerk F, Koch G, van Boven M (2004) Avian influenza A virus (H7N7) epidemic in The Netherlands in 2003: course of the epidemic and effectiveness of control measures. J Infect Dis 190: 2088-2095.

Swayne DE, Suarez DL, Sims LD (2013) Influenza. In Diseases of Poultry, Swayne DE ed, pp 181-218. Wiley-Blackwell.

To KK, Tsang AK, Chan JF, Cheng VC, Chen H, Yuen KY (2014) Emergence in China of human disease due to avian influenza A(H10N8) - cause for concern? J Infect 68: 205-215.

Tong S, Li Y, Rivailler P, Conrardy C, Castillo DA, Chen LM, Recuenco S, Ellison JA, Davis CT, York IA, Turmelle AS, Moran D, Rogers S, Shi M, Tao Y, Weil MR, Tang K, Rowe LA, Sammons S, Xu X, Frace M, Lindblade KA, Cox NJ, Anderson LJ, Rupprecht CE, Donis RO (2012) A distinct lineage of influenza A virus from bats. Proc Natl Acad Sci U S A 109: 4269-4274.

Tong S, Zhu X, Li Y, Shi M, Zhang J, Bourgeois M, Yang H, Chen X, Recuenco S, Gomez J, Chen LM, Johnson A, Tao Y, Dreyfus C, Yu W, McBride R, Carney PJ, Gilbert AT, Chang J, Guo Z, Davis CT, Paulson JC, Stevens J, Rupprecht CE, Holmes EC, Wilson IA, Donis RO (2013) New world bats harbor diverse influenza A viruses. PLoS Pathog, 9: e1003657.

Van Kerkhove MD (2013) Brief literature review for the WHO global influenza research agenda - highly pathogenic avian influenza H5N1 risk in humans. Influenza Other Respir Viruses 7 (Suppl 2): 26-33.

Verhagen JH, Munster VJ, Majoor F, Lexmond P, Vuong O, Stumpel JB, Rimmelzwaan GF, Osterhaus AD, Schutten M, Slaterus R, Fouchier RA (2012) Avian influenza a virus in wild birds in highly urbanized areas. PloS One 7: e38256.

Webster RG, Bean WJ, Gorman OT, Chambers TM, Kawaoka Y (1992) Evolution and ecology of influenza A viruses. Microbiol Rev 56: $152-179$.

Włodarczyk R, Szleszczuk P (2008) Ornithological features of a mute swan (Cyngus olor) flock from the first HPAI H5N1 outbreak in Poland. Med Weter 64: 227-230 (in Polish). 